\title{
Estimation of Yield Losses due to Leaf Rust and Late Seeding on Wheat (Triticum aestivum $L$ ) Variety Seher-06 in District Faisalabad, Punjab, Pakistan
}

\author{
Muhammad Riaz and Yong Wang* \\ Department of Plant Pathology, Agricultural College, Guizhou University, China
}

Submission: July 04, 2017; Published: August 09, 2017

*Corresponding author: Yong Wang, Department of Plant Pathology, Agricultural College, Guizhou University, Guiyang, China, 550025,

Email: yongwangbis@aliyun.com

\begin{abstract}
Wheat is the third important crop in the world and the staple food in Pakistan. Its yield is severely susceptible to a number of factors and diseases such as rust. Leaf rust causes $50 \%$ yield loss in fatal epidemic conditions. The experiment was conducted at Wheat Research Institute (WRI) Faisalabad (Pakistan), where 36 plots of wheat variety (Sehr-06) were sown on November $23^{\text {rd }}, 2013$ and January $2^{\text {nd }}, 2014$, respectively to identify the looses on wheat due to leaf rust and late sowing. Disease data were recorded by COBB's scale. Crop was harvested and threshed by mini thresher. Yield data was recorded in grams. Statistical analysis of data showed that yield losses due to leaf rust were $4.26 \mathrm{~g} / \mathrm{plot}$ and due to late sowing losses were $923.69 \mathrm{~g} /$ plot. The predictability of the analysis revealed that losses due to leaf rust alone were very low. There were also other factors like poor germination, weeds, insect attack, weather conditions, agronomic practices and soil fertility that contributed to lowing yield in Faisalabad.
\end{abstract}

Keywords: COBB's scale; Late sowing; Leaf rust; Regression coefficient; wheat

\section{Introduction}

Wheat is a staple food and contributes about $40 \%$ of the world feeding requirements [1]. Major purpose of wheat cultivation is to ensure food security in agriculturally deficient countries [2]. Its total area under cultivation in Pakistan is 9 million hectares with 23 million tons production [3]. Jellis GJ [4] mentioned that wheat was threatened by many biotic and abiotic factors which led to low yield. Wheat production is endangered by a number of diseases such as leaf rust, stripe rust, stem rust [5]. Insects, specially wheat aphids are mainly biotic devastating factor [6], while salinity, drought, fog, heat and excessive cloudy weather conditions during growing season are abiotic stresses [7].

Leaf rust is more regular and more dominant compared to the other two rusts in Pakistan. Its pathogen requires an alternate host to complete its life cycle [8]. In North America, Puccinia triticina was introduced accompanying with wheat cultivation in the early $17^{\text {th }}$ century, which decreased the wheat production by reducing the number of kernels per head and lower kernel weights [9]. Puccinia triticina is considered now as an important pathogen in wheat growing areas of world, causing significant losses over large regional perspectives [10-13]. In 2007, it led to $14 \%$ loss in Kansas, as the leading wheat-producing state in the USA. Rusted plots yielded $4 \%$ less crops as compared to fungicide-protected plots for cultivars [14]. Yield losses in wheat by leaf rust in cultivar trials were also reported in Mississippi, USA [15]. Due to heavy infection of leaf rust, growth and yield parameter of wheat plants are adversely affected $[16,17]$.

In Pakistan, rusts constantly threat to wheat cropping zones, and leaf rust occurs in epidemic since 1978 [18]. Nearly half yield losses were recorded due to this pathological agent [19]. At present, Pakistan is facing with critical shortage of appropriate wheat varieties, which are capable of ensuring food security, and possessing both features of high yield and rust resistance [6]. Quantification of the damaging effects of the pathogen on diseased plants and inclusion of these damaging functions in crop simulation models is of great importance for a more complete understanding of yield response to disease [20].

The late-sown crop takes less number of growing degree days (GDD) due to whose yield components decreasing and hence the economic yield of the crop sufferring negatively [21]. Ahmad et al. [22] \& Khan et al. (2001) found that planting time 
was on November and delayed planting significantly reduced $1 \%$ yield per day after November. During late temperature of soil it will decrease yield because of less seed germination, tillering capacity, and less productive tillers [23]. Razzaq et al. (2011) suggested that mid November was superior time to planting wheat. Late sowing and unsuitable temperature affect the uniform establishment of wheat crop [24]. Wheat sown during November gave more yield as compare to it after November [25].

\section{Materials and Methods}

The experiment was carried out at Wheat Research Institute (WRI) and Ayub Agricultural Research Institute (AARI), Faisalabad, Punjab, Pakistan during the year 2013-2014. Experiment was laid out in randomize complete block design
(RCBD). Here, randomly, 36 different plots were allocated. The dimensions of each plot was $6 \times 1.62 \mathrm{~m} .100 \mathrm{~g} /$ plot healthy seeds of Sehr-2006 variety were sown by drill in 18 plots at proper soil moisture condition on November 23 ${ }^{\text {rd }}, 2013$ (normal regional sowing) and 18 plots were seeded on January $2^{\text {nd }}, 2014$ (late sowing). After 25 days of sowing, first irrigation was applied, $2^{\text {nd }}$ irrigation was given at tiller stage, $3^{\text {rd }}$ at booting, $4^{\text {th }}$ and $5^{\text {th }}$ irrigation were applied at grain formation stage and milking stage respectively. Fertilizers were applied at recommended dozes. When crop was at milking stage, disease data were recorded by COBB's Peterson scale. Crop was harvested manually on $18^{\text {th }}$ of May and threshing was done with mini thresher in each plot. Yield of each plot was weighed and data was tabulated (Table 1).

Table 1: Disease rating scale used to record rust severity and level of resistance/susceptibility of wheat.

\begin{tabular}{|c|c|c|}
\hline & Field Response & Symptoms \\
\hline R & Immune & $\begin{array}{c}\text { Visible chlorosis or necrosis, no uredia are } \\
\text { present }\end{array}$ \\
\hline MR & Resistant & $\begin{array}{c}\text { Small uredia are present and surrounded by } \\
\text { either chlorotic or necrotic areas }\end{array}$ \\
\hline M & Moderately Resistant & $\begin{array}{c}\text { Variable sized uredia are present some with } \\
\text { chlorosis, necrosis or both }\end{array}$ \\
\hline MS & Intermediate (Mixed) & $\begin{array}{c}\text { Medium sized uredia are present and possibly } \\
\text { surrounded by some chlorotic areas }\end{array}$ \\
\hline S & Moderately susceptible & $\begin{array}{c}\text { Large uredia are present, generally with little } \\
\text { or no chlorosis or necrosis Peterson et al. } \\
(1948)\end{array}$ \\
\hline
\end{tabular}

\section{Results and Discussion}

The present study showed that leaf rust and late sowing contributed to reducing wheat yield. There was a significant difference of yield between control experiment of plot of leaf rust and late sowing plot experiment. Researchers have conducted trials on leaf rust and have established association between the disease epidemic and yield loss of wheat crop. These results are in consistency with the findings of Afzal et al. [26] and Qamar et al. [27], who reported that stripe rust might cause heavy losses in the wheat crop. Leaf rust caused heavy losses all over the world [28]. Environmental factors played an important role in epidemic of leaf rust [29,30]. Salman et al. [31] reported that yield losses increased proportionately with the increase in severity of the disease. Late sowing caused yield losses, and similar result was found by earlier research workers Chaudhry et al. [32], Iqbal et al. [33], Ahmad et al. [22] and Nazir et al. [34]. Ahmed et al. (1997) reported decrease in plant height due to late sowing in wheat (Table $2 \& 3$ ).

Table 2: Statistic analysis of obtained Results.

\begin{tabular}{|c|c|c|c|c|c|c|}
\hline D1 & TRIAL & REP. & L.R(S) & LODG\% & YIELD (gm.)/plot & YIELD(kg/ha) \\
\hline 0 & 1 & 1 & 100 & 90 & 3164 & 3905.958 \\
\hline 0 & 1 & 2 & 100 & 90 & 1424 & 1757.928 \\
\hline 0 & 2 & 1 & 100 & 30 & 3542 & 4372.599 \\
\hline 0 & 2 & 2 & 100 & 20 & 1558 & 1923.351 \\
\hline 0 & 3 & 1 & 100 & 90 & 4062 & 5014.539 \\
\hline 0 & 3 & 2 & 100 & 90 & 1663 & 2052.9735 \\
\hline 0 & 4 & 1 & 60 & 50 & 2625 & 3240.5625 \\
\hline 0 & 4 & 2 & 80 & 80 & 1575 & 1944.3375 \\
\hline 0 & 5 & 1 & 60 & 40 & 4605 & 5684.8725 \\
\hline 0 & 5 & 2 & 70 & 80 & 1595 & 1969.0275 \\
\hline 0 & 6 & 1 & 70 & 90 & 2954 & 3646.713 \\
\hline 0 & 6 & 2 & 60 & 30 & 2450 & 3024.525 \\
\hline 0 & 7 & 1 & 60 & 50 & 3406 & 4204.707 \\
\hline
\end{tabular}


Advances in Biotechnology \& Microbiology

\begin{tabular}{|c|c|c|c|c|c|c|}
\hline 0 & 7 & 2 & 80 & 5 & 2587 & 3193.6515 \\
\hline 0 & 8 & 1 & 70 & 90 & 2630 & 3246.735 \\
\hline 0 & 8 & 2 & 60 & 80 & 2250 & 2777.625 \\
\hline 0 & 9 & 1 & 60 & 80 & 2250 & 2777.625 \\
\hline 0 & 9 & 2 & 80 & 90 & 2610 & 3222.045 \\
\hline 1 & 1 & 1 & 80 & 0 & 2246 & 2772.687 \\
\hline 1 & 1 & 2 & 60 & 0 & 2258 & 2787.501 \\
\hline 1 & 2 & 1 & 60 & 5 & 2238 & 2762.811 \\
\hline 1 & 2 & 2 & 80 & 0 & 2020 & 2493.69 \\
\hline 1 & 3 & 1 & 80 & 0 & 2215 & 2734.4175 \\
\hline 1 & 3 & 2 & 60 & 0 & 2220 & 2740.59 \\
\hline 1 & 4 & 1 & 70 & 0 & 2205 & 2722.0725 \\
\hline 1 & 4 & 2 & 60 & 0 & 2150 & 2654.175 \\
\hline 1 & 5 & 1 & 60 & 0 & 2400 & 2962.8 \\
\hline 1 & 5 & 2 & 60 & 0 & 1705 & 2104.8225 \\
\hline 1 & 6 & 1 & 60 & 0 & 1790 & 2209.755 \\
\hline 1 & 6 & 2 & 60 & 0 & 1700 & 2098.65 \\
\hline 1 & 7 & 1 & 60 & 5 & 1728 & 2133.216 \\
\hline 1 & 7 & 2 & 60 & 0 & 2398 & 2960.331 \\
\hline 1 & 8 & 1 & 60 & 10 & 2030 & 2506.035 \\
\hline 1 & 8 & 2 & 60 & 5 & 1900 & 2345.55 \\
\hline 1 & 9 & 1 & 60 & 0 & 1944 & 2399.868 \\
\hline 1 & 9 & 2 & 60 & 10 & 2082 & 2570.229 \\
\hline
\end{tabular}

Table 3: (Predictor) Unweighted Least Squares Linear Regression of Yield (g/Plot).

\begin{tabular}{|c|c|c|c|c|}
\hline Variables & Coefficient & Std Error & T & P \\
\hline Constant & 3274.42 & 750.563 & 4.36 & 0.0001 \\
\hline LODG & -5.08447 & 5.52493 & -0.92 & $0.3643 \mathrm{NS}$ \\
\hline LR & -4.26618 & 8.57205 & -0.50 & $0.6221 \mathrm{NS}$ \\
\hline D & -923.695 & 423.626 & -2.18 & $0.0367^{*}$ \\
\hline
\end{tabular}

NS indicates non significance.

Wheat plant stopped its vegetative growth just after meeting the photoperiodic requirements which led to shorter height of plant participating the less yield of wheat [35]. Late sowing decreased the wheat production by reducing the spike length (Haider 2000). Maximum grain yield was recorded when planting was done during November. The Present study suggest that November was the optimum time to planting of wheat crop, because crop planted during November produced more tiller, maximum grain yield and more no. of spikes.

Yield=3274.42 - 5.085 Lodg - 4.267 LR - 923.695D

Where D denotes the sowing status ( $0=$ Normal, $1=$ Late). -923.695 coefficient of D showing that if sowing of the variety (Sehar-06) will be done late leads to 924 gram loss per plot.

\section{R-Squared $=0.1817(18.17 \%)$}

R-Squared is the predictability of the regression which is low because there are some other factors to explain the yield those are not actually considered for this study. As from the experiment, it was clear that losses due to leaf rust were not so much. Management of other factors causing low yield enable to obtain good yield from high yield potential variety SEHR-06. Late sowing also contributed to loss yield, because crop got less duration to complete its life cycle. Thus, crop should be sown earlier.

\section{References}

1. Anonymous (2007) The State of Food and Agriculture-2007. Food and Agriculture Organization of the United Nations. Rome, Italy, pp. 251252.

2. Arslan U, Karabulut OA, Yagdi K (2007) Reaction of wheat lines against leaf rust Puccinia triticina in Turkey. Bangladesh J Bot 36(2): 163-166.

3. Anonymous (2009) Agricultural Statistics of Pakistan, Ministry of Food, Agriculture and Livestock, Food and Agriculture Division. (Economic Wing). Islamabad, Pakistan.

4. Jellis GJ (2009) Crop Plant Resistance to Biotic and Abiotic Factors: Combating the Pressures on Production Systems in a Changin World. Crop Plant Resistance to Biotic and Abiotic Factors: Current Potential and Future Demands. Proceedings of the $3^{\text {rd }}$ International Symposium on Plant Protection and Plant Health in Europe, pp. 15-20.

5. Soliman N, Abdelbacki A, Najeeb M, Omara R (2012) Geographical distribution of physiologic races of Puccinia triticina and postulation of resistance genes in new wheat cultivars in Egypt. eSci J Plant Pathol 1(1): 73-80.

6. Hussain M, Ayub N, Khan SM, Khan MA, Muhammad F, et al. (2006) Pyramiding rust resistance and high yield in bread wheat. Pak J Phytopathol 18: 11-21. 
7. Hussain M, Hussain M, Muhammad F, Rehman A, Ahmad N, et al. (2011) Combining high yield potential and durable rust resistance against yellow rust in bread Wheat. Abstracts, International Seminar on Wheat Productivity Enhancement to Sustain Self Sufficiency. March 17. Wheat Research Institute, AARI, Faisalabad-Pakistan 23(1): 56-61.

8. D'Oliveira BD, Samborski DJ (1966) Aecial stage of Puccinia recondita on ranunculaceae and boraginaceae in portugal. In: Macer RC, Wolfe MS (Eds.), Proceedings of the first European Brown Rust Conference, Cambridge, UK, pp. 133-150.

9. Chester KS (1946) The Nature and Prevention of the Cereal Rusts as Exemplified in the Leaf Rust of Wheat. Waltham, MA: Chronica Botanica.

10. Kolmer JA (2005) Tracking wheat rust on a continental scale. Curr Opin Plant Biol 8: 441-449.

11. Marasas CN, Smale M, Singh RP (2004) The Economic Impact in Developing Countries of Leaf Rust Resistance Breeding in CIMMYT related Spring Bread Wheat. DF: International Maize and Wheat Improvement Center, Mexico, pp. 1-38.

12. Roelfs AP, Singh RP, Saari EE (1992) Rust Diseases of Wheat: Concepts and Methods of Disease Management. Mexico, DF: CIMMYT.

13. Saari EE, Prescott JM (1984) World distribution in relation to economic losses. In: Roelfs AP, Bushnell WR (Eds.), Volume 2, The Cereal Rusts, pp. 259-298.

14. Singh RP, Rajaram S (1991) Resistance to Puccinia recondite f. Sp. Tritici in 50 Mexican bread wheat cultivars. Crop Sci 31: 1472-1479.

15. Khan MA, Trevathan LE, Robbins JT (1997) Quantitative relationship between leaf rust and wheat yield in Mississippi. Plant Dis 81: 769772

16. Feyissa R, Kudryavtsev A, Chiapparino E, Chiari T (2005) On-farm conservation and enhancement of local durum Wheat genetic resources in Ethiopia. Proceedings of the XLIX Italian Society of Agricultural Genetics Annual Congress Potenza, Italy, pp. 12-15.

17. Abebe T, Dawit W, Woldeab G (2013) Physiological races and virulence diversity of Puccinia graminis pers. f. sp. Tritici eriks. \& E. Henn. On wheat in tigray region of Ethiopia. eSci J Plant Pathol 2(1): 01-07.

18. Hussain M, Chaudhary MH, Rehaman A, Anwar J, Khan SB (1999) Development of durable rust resistance in wheat. Pak J Phytopath 11: 130-139.

19. Ahmad S, Afzal M, Noorka IR, Iqbal Z, Akhtar N, et al. (2010) Prediction of yield losses in wheat (Triticum aestivum L.) caused by yellow rust in relation to Epidemiological factors in Faisalabad. Pak J Bot 42(1): 401-404.

20. Boote KJ, Jones JW, Mishoe JW, Berger RD (1983) Coupling pests to crop growth simulators to predict yield reductions. Phytopathology 73: 1581-1587.

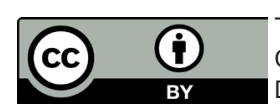

This work is licensed under Creative

Commons Attribution 4.0 Licens

DOI: 10.19080/AIBM.2017.04.555657
21. Lone AH, Shah MH, Bali AS (1999) Yield and economic analysis of different wheat varieties grown on different sowing dates. Applied Biol Res 1: 155-157.

22. Ahmad J, Chaudhry MH, Din S, Ali MA (1996) Stability for grain yield in wheat. Pakistan J Bot 28: 61-65.

23. Shah SM, Akmal M (2002) Effect of different sowing dates on yield and yield components of wheat varieties. Sarhad J Agric 18(2): 143-149.

24. Farooq M, Basra SMA, Rehman M, Saleem BA (2008) Seed priming enhances the performance of late sown wheat by improving chilling tolerance. J Agron Crop Sci 194: 55-60.

25. Akhtar M, Cheema MS, Ali L, Jamil M (2002) Sowing date cum varietal trial on wheat. Asian J Plant Sci 5: 550-551.

26. Afzal SN, Haque MI, Ahmedani MS, Bashir S, Rehman A, et al. (2007) Assessment of yield losses caused by Puccinia striiformis triggering stripe rust in the most Common wheat varieties. Pak J Bot 39(6): 200207.

27. Qamar M, Dilnawaz SA, Shah AH, Wellings C, Batool F, et al. (2008) Postulation of stripe rust resistant genes in some australian bread wheat cultivars and their response to temperature. Pak J Bot 40(6): 2573-2585.

28. Hussain F, Sial RA, Ashraf M (2008) Genetic studies for yield and yield related traits in wheat under leaf rust attack. Int J Agri Biol 10(5): 531535 .

29. Chen XM (2005) Epidemiology and control of stripe rust (Puccinia striiformis f. sp. tritici) on wheat. Can J Plant Pathol 27: 314-337.

30. Dereje H, Chemeda F (2007) Epidemics of stripe rust (Puccinia striiformis) on common wheat (Triticum aestivum) in the highlands of Bale, southeastern Ethiopia. Crop Prot 26(8): 1209-1218.

31. Salman A, Khan MA, Mumtaz Hussain (2006) Prediction of yield losses in wheat varieties/lines due to leaf rust in Faisalabad. Pak J Phytopathol 18(2): 178-182.

32. Chaudhry MH, Anwar J, Hussain F, Khan FA (1995) Effect of planting time on grain yield in wheat varieties. J Agric Res 33: 103-108.

33. Iqbal MS, Yar A, Ali A, Anser MR, Iqbal J, et al. (2001) Effect of sowing dates and seed rate on grain yield of wheat (CV.93- BT-022) J Agric Res 39: 217-221.

34. Nazir MS, Khan A, Ali G, Akhtar M (1980) Relationship between growing periods and yield components of three short duration wheat genotypes. J Agric Res 18: 141-145.

35. Hatam M (1994) Classification of Field Crops. In Crop Production. Bashir E, Bantel R (Eds.), National Book Foundation, Islamabad, Pakistan, p. 22.

\section{Your next submission with Juniper Publishers will reach you the below assets}

- Quality Editorial service

- Swift Peer Review

- Reprints availability

- E-prints Service

- Manuscript Podcast for convenient understanding

- Global attainment for your research

- Manuscript accessibility in different formats

( Pdf, E-pub, Full Text, Audio)

- Unceasing customer service

Track the below URL for one-step submission https://juniperpublishers.com/online-submission.php 